\title{
USING DIGITAL NEWSPAPER AS CREATIVE LEARNING MEDIA TO BOOST STUDENTS' HIGHER THINKING SKILLS
}

\author{
Helda Jolanda Pentury ${ }^{1}$, Anastasia Dewi Anggraeni ${ }^{2}$ \\ Pendidikan Bahasa Inggris, Fakultas Bahasa dan Seni, Universitas Indraprasta PGRI \\ I jolandapentury69@gmail.com, ${ }^{2}$ angelinanasta@gmail.com
}

\begin{abstract}
Abstrak
Melalui aplikasi pedagogis kreatif saat ini, konsep strategi pedagogis yang lebih berorientasi teknologi daripada sebelumnya, dikembangkan dengan mengubah pendidikan melalui perspektif dan motivasi siswa agar lebih kreatif dan inovatif. Konsep penyelarasan Surat Kabar Digital yang diekspresikan dari ilmu sosial dan kemanusiaan telah dikembangkan, guna menciptakan lingkungan akademik yang inovatif dan terampil agar dapat mengintegrasikan pembelajaran kognitif, kinestetik, teknologi, dan sosial-budaya sebagai aspek-aspek pembelajaran. Penelitian ini dilakukan melalui pengamatan terhadap proyek siswa dan mengungkapkan cara mereka mengidentifikasi, mengklasifikasi, menganalisis dan menciptakan proyek pembelajaran kreatif dari topik -topik pada konten Jakarta Post secara daring sebagai media pembelajaran. Hasil penelitian ini menunjukkan bahwa penggunaan media ini secara signifikan mampu meningkatkan kemampuan berpikir siswa secara kritis, kreatif dan inovatif terutama dalam pembelajaran bahasa Inggris. Kami merekomendasikan pada penelitian selanjutnya, para peneliti lebih sering menggunakan surat kabar digital yang berisi berita tentang kehidupan nyata dan memberikan dampak positif agar lebih meningkatkan keterampilan berpikir tingkat tinggi siswa terutama dalam menyelesaikan masalah, menganalisis maupun dalam mengambil keputusan dalam pembelajaran bahasa Inggris.
\end{abstract}

Kata Kunci: Media Kreatif, Keterampilan Bahasa, Keterampilan Berpikir

\begin{abstract}
Through creative pedagogical application currently, the concepts of pedagogical strategy which are more technologically oriented than they used to be, transform education into a way where creative and innovative students' perspectives and motivation are nurtured. Digital Newspaper concept of alignment, which expresses from social science and humanity has been developed useful in creating innovative and skillful academic environments, as it apply to integrate learning with cognitive, kinesthetic, technological, and social-culture aspects learning form. The research conducted by observing students' projects and reveals the way they identify, classify, analyze and create creative learning from the topics of Jakarta Post online content as a learning media. The result of this study shows that using this media which has various current materials can increase students' higher thinking critically, creatively and innovatively in English language learning. We recommend that in future research, researchers use more online newspaper which is more engaging with the real-world and give positive impact to boost students' high order thinking skills to solve the problem, to analyze, and to make decisions in their English language performances.
\end{abstract}

Keywords: Creative Media, Language Skills, Thinking Skills 


\section{INTRODUCTION}

Learning is no longer a matter of acquiring knowledge, but rather an acquisition of strategy of sorting and analyzing knowledge relevant and useful to one's life purposes. Technology can mediate this acquisition of strategy in no insignificant ways, making the transformation in pedagogical way.

After all, as not all knowledge or information presented to students holds relevance to them and comes from credible sources, learning strategies that emphasize such skills as identify, classification, dissection, synthesis, critical evaluation and creation become ineluctably important.

One way to improve the quality of learning that the teaching and learning process is a process that does not only get information from the lecturer but there are many activities and actions that must be done, especially if you want better learning outcomes for students. For example, from giving assignments that stimulate students to think critically and given learning methods and learning models given by the lecturer. The approach to the learning process is essentially a teaching-learning process that emphasizes the importance of learning through the experiential process to gain experience. This approach has a very important role in determining the success or failure of the desired study (Setyowati et al., 2020).

Critical thinking is essential in history because all students need to evaluate, assess, analyze, conceptualize, and judge what is presented as information or facts. Warner (Anggraeni, 2019) states that during the critical thinking phase, teachers have to evaluate the students' fundamental thinking level. In other words, teachers have to assess if the students can think fundamentally, critically, and logically. Additionally, in the collaboration phase, they have to know students' ability to collaborate with their peers in teamwork. Critical thinking is purposeful and reflective judgment about what to believe or do in response to observations, experience, verbal or written expressions, or arguments (Phagwara, 2009).

The media is a means of channeling messages or learning information to be conveyed by the source of the message to the target or recipient of the message. The use of teaching media can help achieve learning success. Danim (Mahnun, 2012) emphasized that the results of research have proven the effectiveness of using tools or media in the teaching and learning process in the classroom, especially in terms of increasing student achievement. The limited media used in the classroom is thought to be one of the causes of the weak quality of student learning.

Media is penetrating cultures and inundating people with information at an everaccelerating pace. Around the world, there is a sharply growing realization among educators that it is essential to teach people to understand the media and their messages. Though the calls for media literacy are not new, what is new is the rise of relatively inexpensive media that allow students to produce their own works, the rapid transnational transmission of programming, and the concerted effort by several countries over the last 2 decades to develop national curricula (Pentury et al., n.d.).

In the context of modern pedagogy, the importance of integrating school subjects into digital tools has begun to catch the attention of teachers. In doing so, teachers have taken steps to implement technology-based education approaches. Since electronic media began to revolutionize the way people obtained information, it also changed the way teachers taught. Thus, teaching students to be higher-thinking persons also requires greater complexity and problem solving. Global trends are provided in newspaper which has global issues as well. In fact, to be higher-thinking students are not only understand 
the fact of the issues, but also to be able to solve the problem or write a scientific report, and able to apply knowledge across disciplines to suggest solutions to problems that have never been encountered before.

Today when students are technology savvy and able to source their learning materials from internet, teachers ought to change their method to more engaging high order thinking activity. Besides, many students change their perspective of learning in digital way. Critical thinking, creativity, written and verbal communication skills, initiative and problem-solving skills capabilities are the lists of qualities to boost the students take part in the learning process enthusiastically. It is important that the teachers' role to deliver their teaching creatively. To further prepare for the students today are equipped with the creative digital media to apply their learning to new situations.

Realizing this, The Jakarta Post is chosen as a creative media because it's a media of communication, present some new categories such as: Social life, language, cultures, Arts, storytelling, Nationalism, Entrepreneurship, and of course headlines news. The articles itself often used style and variation of grammar. Style and grammar are used to attract reader's attention and to make news more interesting. Moreover, The Jakarta Post is available online, which has different style of topics to provide knowledge, language learning and language skills through high thinking projects and activities. The previous research according to Pentury et al., (2020), in creative writing project activities, students' groups learn the content knowledge which is about language skills, such as grammar, part of speech, and vocabulary. To ensure that every student within the group has an opportunity to participate in his or her ideas throughout theirs projects.

The news media select events for reporting according to a complex set of criteria of 'newsworthiness'. Thus, news is not simply what happens out there in the world; it is what is regarded and presented as newsworthy. The 'news values' or criteria according to which events are selected for reporting, are partly shaped by the 'cultural maps' (Bertram et al., 2010).

As we know The Jakarta Post is one of the newspapers written in English for the readers in greater Jakarta. According to Smaldino, Lowther, and Russell (Anggraeni \& Pentury, 2018), media, the plural form of medium, are means of communication. In addition, they state that media are anything that carries information between a source and a receiver. It means that in teaching and learning process, teachers can explain the materials using the learning media in a more concrete way (Anggraeni \& Jolanda, 2018). There are various kinds of media, but visual aids are the appropriate media for learners, particularly young learners. The visual aids which are commonly used for teaching English are pictures, really or real objects, drawings or teacher-made drawings charts, posters, cartoons, and flash cards. Whatever the definitions of media are, there is a guideline which can be stated about media. Media is anything used to send message(s) from the sender(s) to the receiver(s), so it can be aroused the learners ${ }^{\text {ee }}$ thought, feeling, and interest to gear the students ${ }^{\text {ee }}$ learning (Anggraeni \& Jolanda, 2018).

Other research that discusses the media that can improve critical thinking skills is research conducted by Pattanapichet \& Wichadee (2015). Using The Jakarta Post as learning media can make learning more interesting and different by offering variety content for the students to access, including grammar section, vocabulary, global issues as their high thinking activities.

Moreover, teachers conducted the learning activities in things like group work, pair work, discussions and problem solving in project-based learning to present the lessons in new way. Higher thinking learning is about helping children to use their 
imagination, this is intellectual development and being creative enables them to practice their problem solving skills. A good way to promote creative learning is through heuristic play, this involves providing a variety of random objects for a child to make sense of and explore. Students are not only given with information and science but they must be taken to a high level of creating or communicating activities. Achievement of this level in learning theory is known by achieving higher order thinking skills (HOTS) (Syaibani, 2017).

By providing students with practical digital media and high thinking activities to provide high thinking skills development, students can boost their critical thinking, do creative projects and improve their language as well. These innovatory actions are the substance of high thinking learning. Indicators of the feelings attached to creative learning have been gained from research into critical events where real learning and community are its main features (Jeffrey, 2004). Additionally, it is encouraging that using different way of teaching through digital newspaper as teaching context, language learning is also innovative and creative way to engage with global issues as the critical and analytical materials.

\section{RESEARCH METHOD}

Data source is one of the procedures in research method was taken from a daily newspaper entitled The Jakarta Post published online on March 1, 2019 and at once was used as data sources for the students' projects. The learning activities attended by 45 students in third semester 2019/2020 of English department of Indraprastra PGRI University in Jakarta for three months. The following are several steps in collecting data: The whole articles were read, several articles were selected from the newspaper, in this step the selected articles were read thoroughly and repeatedly. Then, The Jakarta Post chosen contents were identified, classified and analyzed through their projects. The method and strategies are applied based on the projects given and Bloom's taxonomy approach. The students do the higher-level order thinking activities where they began to apply the knowledge from the articles, analyze, evaluate and create. Bloom taxonomy approach promotes the formation of learning language in higher thinking activities through digital media.

\section{RESULT AND DISCUSSION}

The analysis of the data is done by identifying, classifying, comparing and contrasting the selected contents of the digital newspaper based on Bloom theory. Here are the data:

Table 1 Identifying, Classifying, Comparing and Contrasting the Contents of the Digital Newspaper

\begin{tabular}{|c|c|c|c|c|c|c|}
\hline Content & $\begin{array}{c}\text { Newspaper } \\
\text { Columns }\end{array}$ & Language Skills & Activities & $\begin{array}{c}\text { Methods \& } \\
\text { Strategies }\end{array}$ & Life Skills & $\begin{array}{c}\text { Thinking } \\
\text { Skill } \\
\text { Levels } \\
\end{array}$ \\
\hline $\begin{array}{l}\text { "Trump, } \\
\text { Kim walk } \\
\text { away" }\end{array}$ & $\begin{array}{l}\text { Headline } \\
\text { News }\end{array}$ & $\begin{array}{l}\text { Student uses a } \\
\text { variety of } \\
\text { strategies using } \\
\text { Mind Mapping to } \\
\text { analyze the topic, } \\
\text { main idea and } \\
\text { supporting details. } \\
\text { (Language skills: } \\
\text { Reading, Writing) }\end{array}$ & $\begin{array}{l}\text { Students take an } \\
\text { article from the } \\
\text { headline news } \\
\text { section. As they } \\
\text { skim the news, } \\
\text { they understand } \\
\text { the news and } \\
\text { analyze it. }\end{array}$ & $\begin{array}{l}\text { Discussion, } \\
\text { Reading } \\
\text { comprehension, }\end{array}$ & $\begin{array}{l}\text { Initiation, } \\
\text { Communicatio, } \\
\text { collaboration, } \\
\text { critical thinking }\end{array}$ & $\begin{array}{l}\text { Analysis \& } \\
\text { Synthesis }\end{array}$ \\
\hline
\end{tabular}




\begin{tabular}{|c|c|c|c|c|c|c|}
\hline $\begin{array}{l}\text { "Young } \\
\text { Indonesians } \\
\text { win Golden } \\
\text { tickets to } \\
\text { Broadway" }\end{array}$ & Features & $\begin{array}{l}\text { Student analyzed } \\
\text { the content, got } \\
\text { the ideas and } \\
\text { expressed the } \\
\text { creativity of how } \\
\text { young } \\
\text { Indonesians won } \\
\text { the golden tickets. } \\
\text { Reading: } \\
\text { Skimming, } \\
\text { scanning, } \\
\text { interference) }\end{array}$ & $\begin{array}{l}\text { Have students } \\
\text { select an article } \\
\text { from the article. } \\
\text { As they skim the } \\
\text { content, they } \\
\text { compare and } \\
\text { contrast the } \\
\text { characteristics of } \\
\text { the winner young } \\
\text { Indonesians }\end{array}$ & $\begin{array}{l}\text { Discussion, } \\
\text { comparing, } \\
\text { contrasting and } \\
\text { Reading } \\
\text { Comprehension }\end{array}$ & $\begin{array}{l}\text { Creativity } \\
\text { Communication } \\
\text { Collaboration } \\
\text { Initiation, } \\
\text { critical thinking, } \\
\text { imagination, } \\
\text { inspiration \& } \\
\text { Motivation }\end{array}$ & $\begin{array}{l}\text { Analysis, } \\
\text { synthesis \& } \\
\text { Evaluation }\end{array}$ \\
\hline $\begin{array}{l}\text { "Palestinian } \\
\text { folk Music } \\
\text { taste at home } \\
\text { for } \\
\text { Refugees" }\end{array}$ & $\begin{array}{l}\text { WORLD } \\
\text { (theme: } \\
\text { Culture) }\end{array}$ & $\begin{array}{l}\text { Student identifies } \\
\text { details classified } \\
\text { and uses } \\
\text { information to } \\
\text { construct meaning } \\
\text { and make } \\
\text { inferences } \\
\text { (reading and } \\
\text { writing). }\end{array}$ & $\begin{array}{l}\text { Students skim \& } \\
\text { scan through the } \\
\text { article to identify, } \\
\text { classify the } \\
\text { characteristics of } \\
\text { folk music and } \\
\text { describe their } \\
\text { interests in folk's } \\
\text { music, They can } \\
\text { make a list of the } \\
\text { characteristics by } \\
\text { analyzed and give } \\
\text { their evaluation. }\end{array}$ & $\begin{array}{l}\text { Project of } \\
\text { various folk } \\
\text { music } \\
\text { characteristics } \\
\text { images. }\end{array}$ & & $\begin{array}{l}\text { Analysis, } \\
\text { synthesis, } \\
\text { Creativity } \\
\& \\
\text { Evaluation }\end{array}$ \\
\hline $\begin{array}{l}\text { "Go-jek } \\
\text { launches } \\
\text { operations in } \\
\text { Thailand" }\end{array}$ & $\begin{array}{l}\text { Business } \\
\text { (Economy } \\
\text { in Brief) }\end{array}$ & $\begin{array}{l}\text { Student correctly } \\
\text { identifies the } \\
\text { difference } \\
\text { impression of how } \\
\text { Go-jek influenced } \\
\text { the lives of } \\
\text { Indonesian people } \\
\text { and Thailand by } \\
\text { giving their } \\
\text { opinions (reading } \\
\text { and writing). }\end{array}$ & $\begin{array}{l}\text { Students express } \\
\text { their opinions by } \\
\text { analyzing and } \\
\text { evaluating the } \\
\text { content. }\end{array}$ & $\begin{array}{l}\text { Analyzing the } \\
\text { content, } \\
\text { evaluating and } \\
\text { giving their } \\
\text { opinions and } \\
\text { ideas. }\end{array}$ & $\begin{array}{l}\text { Creativity } \\
\text { Imagination } \\
\text { Critical and } \\
\text { analytical } \\
\text { Thinking \& } \\
\text { problem solving } \\
\text { Collaboration }\end{array}$ & $\begin{array}{l}\text { Analyzing, } \\
\text { creating, } \\
\text { and } \\
\text { evaluating. }\end{array}$ \\
\hline $\begin{array}{l}\text { "Growing } \\
\text { with } \\
\text { Technology" }\end{array}$ & Business & $\begin{array}{l}\text { Students correctly } \\
\text { analyze, evaluate, } \\
\text { and create the } \\
\text { content in } \\
\text { designing thinking } \\
\text { of life skills } \\
\text { (reading, speaking } \\
\text { and writing). }\end{array}$ & $\begin{array}{l}\text { Review the } \\
\text { picture in the } \\
\text { article briefly. } \\
\text { Then have them } \\
\text { create a story the } \\
\text { topic related. }\end{array}$ & $\begin{array}{l}\text { Source: } \\
\text { https://uxdesign } \\
\text {.cc/how-does- } \\
\text { traditional- } \\
\text { storytelling- } \\
\text { relate-to-brand- } \\
\text { storytelling- } \\
\text { emotional- } \\
\text { intelligence }\end{array}$ & $\begin{array}{l}\text { Creativity } \\
\text { Imagination } \\
\text { Critical and } \\
\text { analytical- } \\
\text { Thinking } \\
\text { Collaboration }\end{array}$ & $\begin{array}{l}\text { Analyzing, } \\
\text { creating, } \\
\text { and } \\
\text { evaluating. } \\
\text { Designing } \\
\text { thinking to } \\
\text { create and } \\
\text { technology } \\
\text { in daily } \\
\text { life. }\end{array}$ \\
\hline Ads & $\begin{array}{l}\text { Classified } \\
\text { Ads. }\end{array}$ & $\begin{array}{l}\text { Student organizes } \\
\text { ideas and } \\
\text { information for } \\
\text { Compare and } \\
\text { contrast analysis. } \\
\text { (Reading } \\
\text { \&writing). }\end{array}$ & $\begin{array}{l}\text { Students explore } \\
\text { how to compare } \\
\text { and make the } \\
\text { contrast of } \\
\text { classified ads. } \\
\text { Look to the ads, } \\
\text { and make graphic } \\
\text { organizer based } \\
\text { on it. }\end{array}$ & $\begin{array}{l}\text { Source: } \\
\text { https://www.res } \\
\text { earchgate.net/fi } \\
\text { gure/Four- } \\
\text { examples-of- } \\
\text { graphic- } \\
\text { organizers-as- } \\
\text { visual- } \\
\text { supports_fig1_3 } \\
\text { 04013010 }\end{array}$ & $\begin{array}{l}\text { Creativity } \\
\text { Imagination } \\
\text { Critical and } \\
\text { analytical- } \\
\text { Thinking, } \\
\text { problem solving } \\
\text { Collaboration }\end{array}$ & $\begin{array}{l}\text { Analyzing, } \\
\text { creating, } \\
\text { and } \\
\text { evaluating }\end{array}$ \\
\hline
\end{tabular}




\begin{tabular}{|c|c|c|c|c|c|c|}
\hline $\begin{array}{l}\text { All articles in } \\
\text { Sport } \\
\text { Sections }\end{array}$ & SPORT & $\begin{array}{l}\text { Student uses } \\
\text { writing process } \\
\text { effectively for } \\
\text { persuasion } \\
\text { (listening, } \\
\text { speaking, reading, } \\
\text { \& writing). }\end{array}$ & $\begin{array}{l}\text { Students design } \\
\text { how athletes work } \\
\text { and set the } \\
\text { strategies they } \\
\text { made to achieve } \\
\text { their goals to get } \\
\text { their } \\
\text { achievements } \\
\text { \&produce money. }\end{array}$ & $\begin{array}{l}\text { Goals \& } \\
\text { Achievements } \\
\text { Projects, } \\
\text { Promotion and } \\
\text { Presentation } \\
\\
\text { Source:https://w } \\
\text { ww.vectorstock. } \\
\text { com/royalty- } \\
\text { free- } \\
\text { vector/managers } \\
\text {-and-office- } \\
\text { workers-on- } \\
\text { business- } \\
\text { training-vector }\end{array}$ & $\begin{array}{l}\text { Creativity } \\
\text { Imagination } \\
\text { Critical and } \\
\text { analytical- } \\
\text { Thinking, } \\
\text { problem solving } \\
\text { Collaboration }\end{array}$ & $\begin{array}{l}\text { Analyzing, } \\
\text { creating, } \\
\text { and } \\
\text { evaluating }\end{array}$ \\
\hline
\end{tabular}

From the data above, there are six chosen contents of The Jakarta Post that used to analyze, synthesize and evaluate in the projects given. There are four language skills used in the activities with various methods and strategy of learning. Besides that, the life skills used practically and effectively to boost their thinking skills based on the learning activities and projects results. They are:

1) The six contents: Headline news, Features, Business in Brief Business, Business image, Classified Ads and Sport.

2) Four language skills: listening, speaking, reading, and writing.

3) Activities learning: knowledge, comprehension, application, analysis, synthesis, and evaluation.

4) Methods are used: Discussion, Inquiry, Projects, Storytelling and presentation.

The mostly analysis text used in The Jakarta Post contents develop students language skills effectively. The articles also contain some features, information and creative texts in good grammar and new vocabularies, so that students can develop their writing and reading performances well. The projects also provided practical learning through various projects with their various issues that boost their thinking and analytical thinking skills by giving the presentation to share their problem solving and new ideas. In addition, students were becoming more critical and more efficient way to be more productive with language, as they were able to explore subjects further through digital newspaper as materials.

The inclusion of digital and media literacy in formal education can be a bridge across digital divides and cultural enclaves, a way to energize learners and make connections across subject areas, and a means for providing more equal opportunities in digital environments (Lee et al., 2012). Furthermore, The Jakarta Post as a digital media provides learning abundant materials to engage students' critical thinking activities and collaborate them with language and digital skills as well.

According to Nadia Mirela Florea and Elena Hurjui (Setyowati et al., 2020), critical thinking is a fundamental ability developed by teachers in learning. Students are better using their skills in using technology by applying their skills in exploring the information critically and also get the fun situations by doing creative learning. From the text above the learning process is really up to date because the activities are supported by relevant topic which is related with the syllabus and the real situations provided. The topics are also engage with the daily life that students can explore their both thinking skills and life skills by using digital newspaper, The Jakarta Post online as learning media in high thinking activities.

In line with the results of other studies that news-literacy proponents would do well to better demonstrate its effectiveness in promoting critical thinking and increasing 
student interest in consuming quality information (Powers, 2010). Critical thinking is indispensable in real life, especially in the field of education, because critical thinking in education is the process of thinking to make decisions from various foundations such as evidence, methods, criteria, context, and conceptualization and relevant sources of information. In the end, this can be practiced by students in real life (Setyowati et al., 2020).

\section{CONCLUSION}

By analyzing the students' projects using The Jakarta Post online, we found that the students' designing thinking skills are better and encourage them to set, create high thinking order model in learning process in practical way. The contents of The Jakarta Post provide four language skills in various activities, using kinds of methods, strategies, projects and diverse meaningful life skill support the high thinking learning-teaching process creatively and boost students' critical and analytical thinking skills significantly that they can apply both in academic and society.

\section{REFERENCES}

Anggraeni, A. D. (2019). Anggraeni, A. D. (2020). Blended humor and mind mapping in improving 21st century skills. Jurnal Ilmu Pendidikan, 25(1), 1-5.

Anggraeni, A. D., \& Pentury, H. J. (2018). Using graphic organizer as a media in students' writing project. Scope: Journal of English Language Teaching, 2(2), 105-111.

Anggraeni, A. D., \& Pentury, H. J. (2018). Using graphic organizer as a media in students' writing project. Scope: Journal of English Language Teaching, 2(02), 105. https://doi.org/10.30998/scope.v2i02.2307

Bertram, W. C., Ranby, P., Adendorff, M., Reed, Y., \& Roberts, N. (2010). Using media in teaching. South African Institute for Distance Education.

Jeffrey, B. (2004). Meaningful creative learning: Learners' perspectives. Paper presented at the European Conference on Educational Research, University of Crete, Please do not quote without permission Bob Jeffrey The Open University Milton Keynes England Email : r.a.jef. September, 22-25.

Lee, J. K., Park, J. W., Kim, Y. H., \& Baek, S. H. (2012). Association between PAX9 single-nucleotide polymorphisms and nonsyndromic cleft lip with or without cleft palate. In The Aspen Institute (Vol. 23, Issue 5). https://doi.org/10.1097/SCS.0b013e31824e27c7

Mahnun, N. (2012). Media pembelajaran (Kajian terhadap langkah-langkah pemilihan media dan implementasinya dalam pembelajaran). An-Nida', 37(1), 27-35.

Pattanapichet, F., \& Wichadee, S. (2015). Using space in social media to promote undergraduate students' critical thinking skills. Turkish Online Journal of Distance Education, 16(4), 38-49. https://doi.org/10.17718/tojde.94170

Pentury, H. J., Anggraeni, A. D., \& Pratama, D. (2020). Improving student' 21st century 
Skills through creative writing as a creative media. Deiksis, 12(02), 164-178. https://doi.org/10.30998/deiksis.v12i02.5184

Phagwara, P. (2009). Newspaper Reading among college students in development of their abstract submitted to lovely school of education in partial fulfillment of the requirement for the award of the degree of master of philosophy in education (Issue 10803230).

Powers, E. (2010). Teaching news literacy in the age of new media (Issue January) [Washington University in St. http://scholar.google.com/scholar?start=160\&hl=en\&as_sdt=2005\&sciodt=0,5\& cites $=12678958180949279741 \&$ scipsc $=\# 7$

Setyowati, R. N., Sari, M. M. K., \& Habibah, S. M. (2020). Improving Critical thinking skills of students through the development of teaching materials. October. https://doi.org/10.2991/icss-18.2018.50

Syaibani, H. A., Dafik., \& Hobri. (2017). TheAnalysis of student's creative thinking skillsin solving "rainbow connection" problemthrough research based learning. The International Journal of Social Sciences and Humanities Invention, 4(8), 3783-3788. https://doi.org/10.18535/ijsshi/v4i8.14 